\title{
Article \\ Characterization of the Novel Phage vB_VpaP_FE11 and Its Potential Role in Controlling Vibrio parahaemolyticus Biofilms
}

\author{
Meiyan Yang ${ }^{1,2,+}{ }^{+}$, Hanfang Chen ${ }^{1,3,+}$, Qiaolan Huang ${ }^{3}$, Zhuanbei Xie ${ }^{1,3}$, Zekun Liu ${ }^{1,3}$, Jumei Zhang ${ }^{1,2}$, \\ Yu Ding ${ }^{4}\left(\mathbb{D}\right.$, Moutong Chen ${ }^{1}$, Liang Xue ${ }^{1} \mathbb{D}$, Qingping $W_{u}{ }^{1,2, * \mathbb{D}}$ and Juan Wang ${ }^{2, *}$
}

1 Guangdong Provincial Key Laboratory of Microbial Safety and Health, State Key Laboratory of Applied Microbiology Southern China, Institute of Microbiology, Guangdong Academy of Sciences, Guangzhou 510070, China; ymy@scau.edu.cn (M.Y.); chenhanfangh@163.com (H.C.); xiezhuanbei@163.com (Z.X.); liuzekun98@gmail.com (Z.L.); zhangjm926@126.com (J.Z.); cmtoon@hotmail.com (M.C.); xueliang@gdim.cn (L.X.)

2 College of Food Science, South China Agricultural University, 483 Wushan Road, Guangzhou 510642, China

3 College of Agriculture, South China Agricultural University, 483 Wushan Road, Guangzhou 510642, China; symxmyz3133@163.com

4 Department of Food Science \& Technology, Institute of Food Safety and Nutrition, Jinan University, Guangzhou 510642, China; dingyu@jnu.edu.cn

* Correspondence: wuqp203@163.com (Q.W.); wangjuan@scau.edu.cn (J.W.); Tel./Fax: +86-20-8768-8132 (Q.W.)

+ These authors contributed equally to this work.

\section{check for}

updates

Citation: Yang, M.; Chen, H.;

Huang, Q.; Xie, Z.; Liu, Z.; Zhang, J.;

Ding, Y.; Chen, M.; Xue, L.; Wu, Q.;

et al. Characterization of the Novel

Phage vB_VpaP_FE11 and Its

Potential Role in Controlling Vibrio

parahaemolyticus Biofilms. Viruses

2022, 14, 264. https://doi.org/

$10.3390 /$ v14020264

Academic Editors: Dann Turner

and Mikael Skurnik

Received: 18 November 2021

Accepted: 17 January 2022

Published: 27 January 2022

Publisher's Note: MDPI stays neutral with regard to jurisdictional claims in published maps and institutional affiliations.

Copyright: (C) 2022 by the authors. Licensee MDPI, Basel, Switzerland. This article is an open access article distributed under the terms and conditions of the Creative Commons Attribution (CC BY) license (https:// creativecommons.org/licenses/by/ $4.0 /)$.

\begin{abstract}
Vibrio parahaemolyticus causes aquatic vibriosis. Its biofilm protects it from antibiotics; therefore, a new different method is needed to control V. parahaemolyticus for food safety. Phage therapy represents an alternative strategy to control biofilms. In this study, the lytic Vibrio phage vB_VpaP_FE11 (FE11) was isolated from the sewers of Guangzhou Huangsha Aquatic Market. Electron microscopy analysis revealed that FE11 has a typical podovirus morphology. Its optimal stability temperature and $\mathrm{pH}$ range were found to be $20-50{ }^{\circ} \mathrm{C}$ and $5-10{ }^{\circ} \mathrm{C}$, respectively. It was completely inactivated following ultraviolet irradiation for $20 \mathrm{~min}$. Its latent period is $10 \mathrm{~min}$ and burst size is 37 plaque forming units/cell. Its double-stranded DNA genome is 43,397 bp long, with a $\mathrm{G}+\mathrm{C}$ content of $49.24 \%$ and 50 predicted protein-coding genes. As a lytic phage, FE11 not only prevented the formation of biofilms but also could destroy the formed biofilms effectively. Overall, phage vB_VpaP_FE11 is a potential biological control agent against $V$. parahaemolyticus and the biofilm it produces.
\end{abstract}

Keywords: Vibrio parahaemolyticus; aquaculture; biofilm; phage; biological control

\section{Introduction}

Vibrio parahaemolyticus, a halotolerant Gram-negative bacterium, is an important foodborne pathogen commonly present in aquatic products [1,2]. With the consumption of uncooked seafood becoming a growing trend, the risk of infection with $V$. parahaemolyticus has increased. The clinical symptoms of $V$. parahaemolyticus infections include abdominal pain, diarrhea, nausea, vomiting, and fever $[3,4]$. Furthermore, $V$. parahaemolyticus can cause substantial economic losses in aquaculture industry [5].

Biofilms are important for bacterial growth and survival; V. parahaemolyticus uses them to survive in natural or food-processing environments [6]. Bacterial cells in biofilms are more resistant to antibiotics than planktonic bacteria [7]; hence, V. parahaemolyticus biofilms pose a major threat to food safety.

Bacterial resistance to antibiotics has become increasingly common with the overuse of the latter [8,9]; therefore, it is necessary to develop new effective antimicrobial agents. Bacteriophages, the most abundant biological entities on Earth, reduce the global bacterial population by half every $48 \mathrm{~h}$ via phage predation [10]. In addition, phages are natural entities and highly specific; hence, using them as antimicrobial agent is cost effective. 
Studies on phage therapy have demonstrated its potential as an alternative to antibiotic therapy; for example, phages can be used to control Vibrio infection in the culture of aquatic organisms such as sea cucumbers [11,12] and Atlantic salmon [13]. Phage therapy has also been used to control the formation of Vibrio biofilms [14,15].

In this study, a $V$. parahaemolyticus phage was isolated from sewage. The phage was preliminarily classified by morphology using transmission electron microscopy (TEM). BLASTn and ANIm were used to compare the nucleotide sequence and combined with the results of TEM to further classify the phage. Phylogenetic trees were used to determine the phylogenetic relationships of phage. Finally, the phage was classified at the genus level using vConTACT. There are few studies on the control of $V$. parahaemolyticus biofilms by phages. We investigated the control effects of phage vB_VpaP_FE11 (FE11) on $V$. parahaemolyticus biofilms in vitro. These results will broaden our knowledge about $V$. parahaemolyticus phage and potentially provide a theoretical basis with which to treat V. parahaemolyticus biofilms.

\section{Materials and Methods}

\subsection{Bacterial Strains and Growth Conditions}

All $V$. parahaemolyticus strains used in this study were provided by the Institute of Microbiology, Guangdong Academy of Sciences and were stored at $-80{ }^{\circ} \mathrm{C}$ in $30 \%(v / v)$ glycerol (Table 1). V. parahaemolyticus strain O5-15 (VP O5-15, antigen O5 and strain no. 15) was isolated from infected shrimp and incubated at $37^{\circ} \mathrm{C}$ in tryptic soy broth (TSB) while being shaken at 200 rpm overnight.

Table 1. Host range for FE11 against Vibrio parahaemolyticus (VP) strains.

\begin{tabular}{|c|c|c|c|c|c|c|c|c|c|c|c|}
\hline $\begin{array}{c}\text { VP } \\
\text { Strains }\end{array}$ & Serotype & FE11 & $\begin{array}{c}\text { VP } \\
\text { Strains }\end{array}$ & Serotype & FE11 & $\begin{array}{c}\text { VP } \\
\text { Strains }\end{array}$ & Serotype & FE11 & VP Strains & Serotype & FE11 \\
\hline O1-1 & O1 & - & O2-91 & $\mathrm{O} 2$ & + & O4-112 & $\mathrm{O} 4$ & - & O10-127 & O10 & - \\
\hline O1-2 & O1 & + & O2-92 & $\mathrm{O} 2$ & - & O4-113 & $\mathrm{O} 4$ & + & O10-128 & O10 & - \\
\hline O1-3 & O1 & + & O2-93 & $\mathrm{O} 2$ & - & O4-114 & $\mathrm{O} 4$ & + & O10-129 & $\mathrm{O} 10$ & - \\
\hline O1-4 & O1 & - & O2-94 & $\mathrm{O} 2$ & - & O4-115 & $\mathrm{O} 4$ & - & O10-130 & $\mathrm{O} 10$ & -- \\
\hline O1-36 & O1 & - & O2-95 & $\mathrm{O} 2$ & - & O5-15 & O5 & + & O10-131 & O10 & - \\
\hline O1-37 & O1 & - & O2-96 & $\mathrm{O} 2$ & - & O5-16 & O5 & - & O10-132 & O10 & - \\
\hline O1-38 & O1 & - & O2-97 & $\mathrm{O} 2$ & + & O5-17 & O5 & - & O11-29 & O11 & - \\
\hline O1-62 & O1 & - & O2-98 & $\mathrm{O} 2$ & - & O5-49 & O5 & - & O11-30 & O11 & + \\
\hline O1-63 & O1 & + & O2-99 & $\mathrm{O} 2$ & - & O5-50 & O5 & - & O11-31 & O11 & + \\
\hline O1-64 & O1 & + & O2-100 & $\mathrm{O} 2$ & - & O5-116 & O5 & - & O11-56 & O11 & - \\
\hline O1-65 & O1 & - & O2-101 & $\mathrm{O} 2$ & + & O5-117 & O5 & - & O11-57 & O11 & - \\
\hline O1-66 & O1 & - & O2-102 & $\mathrm{O} 2$ & - & O5-118 & O5 & - & O11-58 & O11 & - \\
\hline O1-67 & O1 & + & O2-103 & $\mathrm{O} 2$ & - & O6-18 & O6 & + & O11-133 & O11 & + \\
\hline O1-68 & O1 & - & O3-8 & $\mathrm{O} 2$ & - & O6-19 & O6 & + & O11-134 & O11 & + \\
\hline O1-69 & O1 & - & O3-9 & $\mathrm{O} 2$ & - & O6-20 & O6 & + & O11-135 & O11 & + \\
\hline O1-70 & O1 & - & O3-10 & $\mathrm{O} 3$ & - & O6-120 & O6 & - & O11-136 & O11 & - \\
\hline O1-71 & O1 & - & O3-11 & $\mathrm{O} 3$ & - & O8-21 & O8 & + & O11-137 & O11 & + \\
\hline O1-72 & O1 & + & O3-42 & $\mathrm{O} 3$ & - & O8-22 & O8 & - & O11-138 & O11 & - \\
\hline O1-73 & O1 & - & O3-43 & $\mathrm{O} 3$ & - & O8-51 & O8 & - & O12-32 & O12 & - \\
\hline O2-5 & $\mathrm{O} 2$ & - & O3-44 & $\mathrm{O} 3$ & - & O8-52 & O8 & - & O12-33 & O12 & + \\
\hline $\mathrm{O} 2-6$ & $\mathrm{O} 2$ & - & O3-104 & $\mathrm{O} 3$ & + & O8-53 & O8 & - & O12-34 & O12 & - \\
\hline $\mathrm{O} 2-7$ & $\mathrm{O} 2$ & - & O3-105 & $\mathrm{O} 3$ & - & O8-121 & $\mathrm{O} 8$ & - & O12-35 & O12 & - \\
\hline O2-39 & $\mathrm{O} 2$ & - & O3-106 & $\mathrm{O} 3$ & + & O8-122 & O8 & + & O12-60 & O12 & - \\
\hline O2-40 & $\mathrm{O} 2$ & - & O3-107 & $\mathrm{O} 3$ & + & O8-123 & $\mathrm{O} 8$ & - & O12-61 & O12 & - \\
\hline O2-41 & $\mathrm{O} 2$ & - & O4-12 & $\mathrm{O} 4$ & + & O8-124 & O8 & - & O12-140 & O12 & - \\
\hline O2-82 & $\mathrm{O} 2$ & - & O4-14 & O4 & + & O8-125 & $\mathrm{O} 8$ & - & O12-141 & O12 & - \\
\hline
\end{tabular}


Table 1. Cont.

\begin{tabular}{|c|c|c|c|c|c|c|c|c|c|c|c|}
\hline $\begin{array}{c}\text { VP } \\
\text { Strains }\end{array}$ & Serotype & FE11 & $\begin{array}{c}\text { VP } \\
\text { Strains }\end{array}$ & Serotype & FE11 & $\begin{array}{c}\text { VP } \\
\text { Strains }\end{array}$ & Serotype & FE11 & VP Strains & Serotype & FE11 \\
\hline $\mathrm{O} 2-83$ & $\mathrm{O} 2$ & - & O4-45 & $\mathrm{O} 4$ & - & O8-126 & O8 & - & O12-143 & O12 & - \\
\hline O2-84 & $\mathrm{O} 2$ & - & O4-46 & $\mathrm{O} 4$ & - & O9-24 & O9 & - & O12-144 & O12 & - \\
\hline O2-85 & $\mathrm{O} 2$ & - & O4-47 & $\mathrm{O} 4$ & + & O10-25 & O10 & - & O12-145 & O12 & - \\
\hline O2-86 & $\mathrm{O} 2$ & - & O4-48 & $\mathrm{O} 4$ & - & O10-26 & O10 & - & O12-146 & O12 & + \\
\hline O2-87 & $\mathrm{O} 2$ & - & O4-108 & $\mathrm{O} 4$ & - & O10-27 & O10 & + & O12-147 & O12 & - \\
\hline O2-88 & $\mathrm{O} 2$ & - & O4-109 & $\mathrm{O} 4$ & + & O10-28 & O10 & - & & & \\
\hline O2-89 & $\mathrm{O} 2$ & - & O4-110 & $\mathrm{O} 4$ & - & O10-54 & O10 & + & & & \\
\hline O2-90 & $\mathrm{O} 2$ & - & O4-111 & $\mathrm{O} 4$ & + & O10-55 & O10 & - & & & \\
\hline
\end{tabular}

\subsection{Phage Isolation and Purification}

Phages were isolated from the sewage taken from Huangsha Aquatic Market in Guangzhou. The sewage sample was centrifuged at $5000 \times g$ for $10 \mathrm{~min}$, following which the supernatant was suction-filtered using the $0.45 \mu \mathrm{m}$ (47 $\mathrm{mm}$ diameter) mixed cellulose ester GSWP filter (HuanKai Microbial, Guangzhou, China). Thereafter, $\mathrm{MgSO}_{4}$ was added to a final concentration of $50 \mathrm{mM}$ for phage particles gathering, the mixture was allowed to stand for $10 \mathrm{~min}$ before being suction-filtered again using a $0.22-\mu \mathrm{m}$ filter [16]. The filter membranes were cut and eluted with a broth containing 3\% (w/v) Bacto beef extract, $3 \%(v / v)$ Tween 80 and $50 \mathrm{mM} \mathrm{NaCl}$. Subsequently, $2 \mathrm{~mL}$ of eluent and $100 \mu \mathrm{L}$ of early log-phase VP O5-15 cultures were mixed with $2 \mathrm{~mL}$ of double-strength TSB supplemented with $4 \mathrm{mM} \mathrm{CaCl}_{2}$, and incubated overnight at $37{ }^{\circ} \mathrm{C}$ while being shaken $(200 \mathrm{rpm})$. The culture was then filtered through the $0.45 \mu \mathrm{m}$ syringe filter. The process was repeated three times. Phage presence was verified using a double-layered plate. A suitable dilution of phage (approximately $1 \times 10^{3}$ plaque forming units (pfu) $/ \mathrm{mL}, 100 \mu \mathrm{L}$ ) was mixed with $100 \mu \mathrm{L}$ of VP O5-15, added to $5 \mathrm{~mL}$ TSB with $0.4 \%$ agar $(2 \mathrm{mM} \mathrm{CaCl} 2)$, poured onto a $1.5 \%$ TSB agar plate, and incubated at $37^{\circ} \mathrm{C}$ for $5 \mathrm{~h}$. Finally, a single isolated plaque was selected and purified at least six times. The purified phage was stored at $4{ }^{\circ} \mathrm{C}$ for later use.

\subsection{Transmission Electron Microscopy (TEM) Analysis}

The method of Ajuebor et al. [17] was followed with minor modifications. Before TEM analysis, the phage was concentrated using gradient centrifugation. Cesium chloride solutions $(2.5 \mathrm{~mL}$ of $1.3 \mathrm{~g} / \mathrm{mL}, 1.5 \mathrm{~g} / \mathrm{mL}$, and $1.7 \mathrm{~g} / \mathrm{mL})$ were layered sequentially to a 10-mL Beckman centrifuge tube to which $2.5 \mathrm{~mL}$ of the concentrated phage solution was added. Thereafter, the solution was centrifuged using a SW 41 Ti rotor (Optima XPN-100 ultracentrifuge, Beckman Coulter, Brea, CA, USA) at 200,600 $\times g$ for $3 \mathrm{~h}$ at $4{ }^{\circ} \mathrm{C}$. After centrifugation, the phages formed a bluish-white band at the interface between 1.3 and $1.5 \mathrm{~g} / \mathrm{mL} \mathrm{CsCl}[18]$. The phage particles were collected by suctioning with a syringe placed just underneath the target band. The collected phages were negatively stained with $2 \%(w / v)$ phosphotungstic acid on a carbon-coated grid and examined using a transmission electron microscope (Hitachi H-7650, Tokyo, Japan).

\subsection{Phage Host Range}

$V$. parahaemolyticus has been classified to 13 types based on its LPS O antigens [19]. Phage host range was determined using $133 \mathrm{~V}$. parahaemolyticus strains that represent the different $\mathrm{O}$ types. First, $100 \mu \mathrm{L}$ of early log-phase bacterial culture was mixed with $5 \mathrm{~mL}$ of warm soft agar (TSB containing $0.4 \%$ agar, $2 \mathrm{mM} \mathrm{CaCl}_{2}$ ) and poured onto $1.5 \%$ TSA plates, following which $2 \mu \mathrm{L}$ drops of 10-fold diluted phage stock were pipetted on each plate. Thereafter, the plates were incubated at $37^{\circ} \mathrm{C}$ and observed after $5 \mathrm{~h}$. Phage hosts were confirmed by the appearance of distinct plaques on the plate. 


\subsection{Isolation, Genome Sequencing, and Assembly of Phage DNA}

Phage DNA was extracted according to Zhao et al. [20,21] with some modifications. Briefly, the phage was precipitated overnight with 15\% (w/v) PEG 8000 and $0.5 \mathrm{M} \mathrm{NaCl}$ at $4{ }^{\circ} \mathrm{C}$. Subsequently, the phage was centrifuged at $12,000 \times \mathrm{g}$ for $20 \mathrm{~min}$ and then resuspended in SM buffer. The concentrated phage particles were treated with DNase I (final concentration 0.1 units $/ \mu \mathrm{L}$ ) and RNase A (final concentration $3 \mu \mathrm{g} / \mathrm{mL}$ ) to remove bacterial genomic contamination. Thereafter, the sample was treated with SDS, EDTA, and proteinase K. Finally, the phage DNA was extracted using phenol-chloroform-isoamyl alcohol (25:24:1). The DNA was sequenced using the Ion Torrent S5 platform (Thermo Fisher Scientific, Waltham, MA, USA) and high-quality reads were subsequently assembled using SPAdes v. 3.12.0.

\subsection{Genome Analysis and Phylogenetic Analysis}

PhageTerm was used to identify phage termini and reassemble the whole genome sequence of FE11 [22]. The genome data was analyzed using the National Center for Biotechnology Information (NCBI) database (https: / / blast.ncbi.nlm.nih.gov / Blast.cgi accessed on 18 November 2021). The genome sequences of 24 Podoviridae members of Vibrio parahaemolyticus were downloaded from NCBI. Similarities between genomic sequences were determined using the average nucleotide identity MUMmer (ANIm) [23]. The heatmap was drawn using TBtools. Putative transfer RNA (tRNA)-encoding genes were predicted using tRNAscan-SE. Predicted virulence factors and antibiotic genes were examined using searches against the Virulence Factor Database and the Antibiotic Resistance Gene Database, respectively. The complete genome was automatically annotated by Prokka. Further analysis of the predicted gene products was conducted using BLASTP [24], InterProScan [25] and HHpred [26]. Groups of similar phage genomes were visualized using Easyfig. Phylogenetic analysis based on RNA polymerase was conducted using the neighbor-joining method in MEGA X with 1000 bootstrap replicates [27]. Finally, taxonomic assignment of phage genomes was performed using vConTACT [28] and visualized using the software Cytoscape.

\subsection{One-Step Growth Experiment}

The overnight culture of VP O5-15 was diluted 1:50 to a fresh medium (TSB) and cultured at $37^{\circ} \mathrm{C}, 200 \mathrm{rpm}$ for 1 to $2 \mathrm{~h}$, during which the bacterial cells in $0.1 \mathrm{~mL}$ of the medium were counted every $10 \mathrm{~min}$ using a hemocytometer. The optical density at $600 \mathrm{~nm}$ $\left(\mathrm{OD}_{600}\right)$ of the suspension was also measured. A standard curve was generated and the corresponding viable count was estimated using $\mathrm{OD}_{600}$. A one-step growth curve was generated following a previously described method [29]. Briefly, VP O5-15 was cultured at $37^{\circ} \mathrm{C}$ to the early-exponential growth-phase. One milliliter of the bacterial suspension $\left(1 \times 10^{8}\right.$ colony forming units $\left.(\mathrm{cfu}) / \mathrm{mL}\right)$ was centrifuged at $8000 \times g$ for $5 \mathrm{~min}$, and the pellet was resuspended in $1 \mathrm{~mL}$ of SM buffer $\left(2 \mathrm{mM} \mathrm{CaCl}_{2}\right)$. The phage was added at multiplicity of infection (MOI) $=0.1$, the mixture was swirled gently and incubated at $37^{\circ} \mathrm{C}$ for $10 \mathrm{~min}$. The mixture was centrifuged at $12,000 \times \mathrm{g}$ for $2 \mathrm{~min}$ to remove free phage, and the pellet was suspended in $1 \mathrm{~mL}$ of TSB. Thereafter, $0.1 \mathrm{~mL}$ of this solution was mixed with $9.9 \mathrm{~mL}$ TSB medium $(2 \mathrm{mM} \mathrm{CaCl} 2)$; this step corresponded to time zero $\left(\mathrm{T}_{0}\right)$. Next, the mixed medium was cultured for $40 \mathrm{~min}$ at $37^{\circ} \mathrm{C}, 200 \mathrm{rpm}$. The sample was obtained every 5 min interval to determine the titer of FE11. The experiment was repeated three times. The burst size of the phage was calculated as follows: burst size = the final count of phage / (initial count of phage-titer at $\mathrm{T}_{0}$ ).

\subsection{Effects of Temperature, $p H$, and Ultraviolet (UV) Irradiation on Phage Activity}

To investigate the stability of FE11, the effects of temperature, $\mathrm{pH}$, and UV on phage activity were evaluated as described in another study $[30,31]$. First, the phage suspensions $\left(1.0 \times 10^{8} \mathrm{pfu} / \mathrm{mL}\right.$ were incubated in a water bath at $20,37,40,50,60$, and $70^{\circ} \mathrm{C}$; phage tittering was conducted after $1 \mathrm{~h}$ of incubation. $\mathrm{HCl}$ and $\mathrm{NaOH}$ were used to adjust the 
different $\mathrm{pH}(3,4,5,6,7,8,9,10,11$, and 12) of TSB. Phages were equally added to this TSB and placed for $1 \mathrm{~h}$ at $37^{\circ} \mathrm{C}$. To determine the impact of ultraviolet (UV) irradiation, the phage suspension was exposed to UV light (254 $\mathrm{nm}$ and $25 \mathrm{~W}$ ) and phage titering was carried out every $5 \mathrm{~min}$ for $30 \mathrm{~min}$. Each experiment was repeated three times.

\subsection{Effect of Phages on the Biofilm Formed}

Previously reported methods [32,33] were used, with some modifications, to determine the effect of phages on the biofilm formed. $V$. parahaemolyticus $\left(2.0 \times 10^{6} \mathrm{cfu} / \mathrm{mL}\right)$ was distributed in $200 \mu \mathrm{L}$ aliquots to the wells of a 96-well microtiter plate, and cultured at $28{ }^{\circ} \mathrm{C}$ for $12 \mathrm{~h}$. Thereafter, the medium was removed and each well was washed three times with $200 \mu \mathrm{L}$ of sterile phosphate-buffered saline (PBS). Next, $200 \mu \mathrm{L}$ of FE11 $\left(1 \times 10^{10}\right.$, $1 \times 10^{9}, 1 \times 10^{8}, 1 \times 10^{7}, 1 \times 10^{6}, 1 \times 10^{5}, 1 \times 10^{4}$, and $\left.1 \times 10^{3} \mathrm{pfu} / \mathrm{mL}\right)$ and TSB was added; for the control group, $200 \mu \mathrm{L}$ of TSB was added. The samples were cultured at $28^{\circ} \mathrm{C}$ for $1,2,3,4$, and $5 \mathrm{~h}$. At specific times, one plate was taken out, the medium was removed, and each well was washed three times with $200 \mu \mathrm{L}$ of sterile PBS. Next, $200 \mu \mathrm{L}$ of methanol was added to each well and incubated for $20 \mathrm{~min}$ before removal. After being air-dried, $200 \mu \mathrm{L}$ of $0.1 \%$ crystal violet was added to each well and incubated for $15 \mathrm{~min}$. Excess staining was removed by rinsing with water; thereafter, the plates were dried at $37^{\circ} \mathrm{C}$. Subsequently, 33\% v/v glacial acetic acid was added for elution and the $\mathrm{OD}_{590}$ was measured using a microplate reader (BioTek Instruments Inc., Winooski, VT, USA).

\subsection{Effect of Phages on the Formation of Biofilm}

This experiment used the method described in Section 2.9 with some modifications. Phage FE11 $(100 \mu \mathrm{L})$ was added to the VP O5-15 culture $\left(1.0 \times 10^{8} \mathrm{cfu} / \mathrm{mL}\right)$ at the MOIs of $100,10,1,0.1,0.01,0.001$, and 0.0001 ; SM buffer $(100 \mu \mathrm{L})$ was added to the bacterial culture as a control. A total of $200 \mu \mathrm{L}$ of the culture was added to 96 -well plates. Three identical plates were prepared together and cultured at $28^{\circ} \mathrm{C}$ for 6,9 , and $12 \mathrm{~h}$, respectively. Subsequently, the $\mathrm{OD}_{590}$ was measured as specified in Section 2.9.

\subsection{Scanning Electron Microscopy (SEM) Analysis}

A previously described method [34] was used, with some modifications, for the SEM analysis in which $200 \mu \mathrm{L}$ of phage FE11 $\left(1 \times 10^{10} \mathrm{pfu} / \mathrm{mL}\right)$ and $200 \mu \mathrm{L}$ of VP O5-15 $\left(1 \times 10^{8} \mathrm{cfu} / \mathrm{mL}, \mathrm{MOI}=100\right)$ were added to a 48 -well plate with $8 \mathrm{~mm}$ cell slides at the bottom. The control group had equal amounts of VP O5-15 and TSB. The plates were incubated at $37^{\circ} \mathrm{C}, 12 \mathrm{~h}$. Next, the cell slide was removed using a pair of tweezers and washed twice with $1 \times$ PBS. Each slide was then immobilized with $3 \%$ pentanediol at $4{ }^{\circ} \mathrm{C}$ for $5 \mathrm{~h}$, after which they were dehydrated in a gradient ethanol series $(30 \%, 50 \%, 70 \%$, $90 \%$, and $100 \%$ ), and freeze-dried. Finally, the amount and morphology of biofilm were observed using a scanning electron microscope (Hitachi S-3000 N, Tokyo, Japan).

\subsection{Statistical Analysis}

The data were expressed as mean \pm Standard deviation (SD) and the differences were analyzed with two-way ANOVA using GraphPad Prism 7.0. Significance was considered at $p<0.05$.

\subsection{Accession Number}

The whole genome sequence of phage vB_VpaP_FE11 has been deposited at GenBank under the accession number MT178448.

\section{Results}

\subsection{Isolation and Morphological Characterization of Phage FE11}

TEM analysis (Figure 1) showed that FE11 consist of an icosahedral head (diameter $47 \pm 2 \mathrm{~nm}$ ) and a short, non-contractile tail (length $18 \pm 2 \mathrm{~nm}$ ). This indicated that the phage 
belonged to the family Podoviridae. The phage was named as Vibrio phage vB_VpaP_FE11 as per international nomenclature [35].

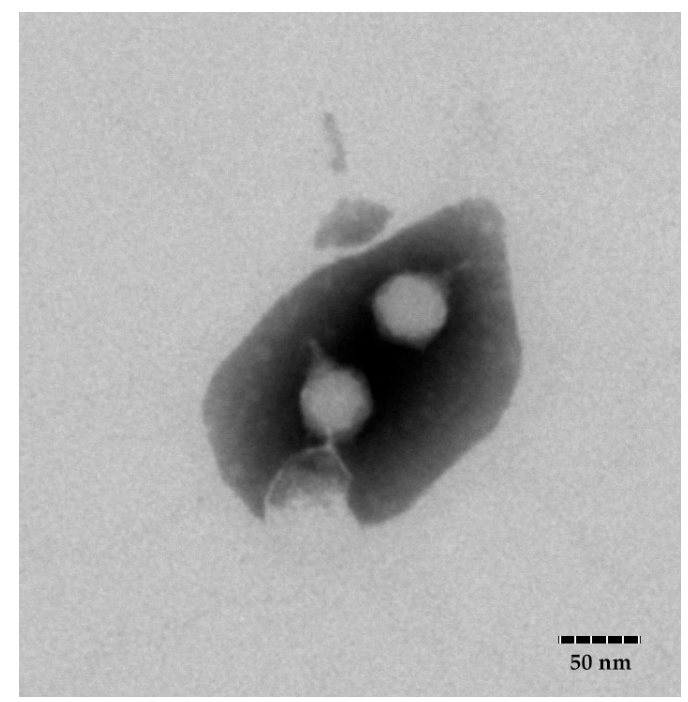

Figure 1. TEM images of vB_VpaP_FE11 (FE11), scale bar $=50 \mathrm{~nm}$.

\subsection{Host Range of Phage FE11}

The 133 strains of V. parahaemolyticus listed in Table 1-including the strain VP O5-15, which was used to isolate phages-were used to determine the antimicrobial spectrum of phage FE11. Host range was determined using spot assays. We found that FE11 could infect 35 of the 133 strains of $V$. parahaemolyticus. Phage FE11 host range was distributed among most of the $11 \mathrm{O}$-serotypes of $V$. parahaemolyticus tested in this study, suggesting that the $\mathrm{O}$-antigen was not the specific receptor of the phage. Interestingly, among the serotype O5 strains it could only infect the original host strain VP O5-15.

\subsection{The Genome Analysis of FE11}

The PhageTerm results indicated that FE11 has redundant ends and headful (pac) phage packaging (Figure S1). The genome of phage FE11 is 43,397 bp long and consists of linear double-stranded DNA with a GC content of $49.24 \%$. It had the highest sequence similarity with the genomes of phage vB_VpaP_KF1 (identity $\times$ coverage $=93 \%$ ) and vB_VpaP_KF2 (identity $\times$ coverage $=92.9 \%$ ) by BLASTn. The ANI heatmap showed that FE11 is distinct from the other phages (Figure 2). The ANIm percentage identity of FE11 with vB_VpaP_KF1 (KF1) and vB_VpaP_KF2 (KF2) were both $93 \%$. Among the 50 predicted genes, 25 showed similarities to genes encoding proteins of known function (Figure 3, Table S1). The remaining 25 predicted genes encoded hypothetical proteins. The FE11 proteins with predicted functions could be categorized into five functional groups: DNA metabolism, structure, lysis, DNA packaging and other function group, which respectively contained 9, 8, 4, 2 and 2 proteins. The predicted RNA polymerase was included in the DNA metabolism group. No tRNA genes were found using the tRNAScan-SE analysis, suggesting that FE11 depends on host translation. Furthermore, there were no virulence and antibiotic resistance genes in the genome of FE11, indicating that it could be safely used to control $V$. parahaemolyticus.

The phage particle morphology and the analysis of the functions of the predicted gene products allowed to conclude that FE11 is a typical member of the Podoviridae. The fact that it has its own RNA polymerase places it, according to the ICTV classification, to the subfamily Autographivirinae. Therefore, the genome sequence of 44 Autographivirinae phages were downloaded from the ICTV database for phylogenetic analysis. The results (Figure 4) showed that FE11, vB_Vc_SrVc9, KF1, and KF2, were clustered in the same branch; this was consistent with the results of the whole genome similarity analysis. Next, 
a protein-sharing network was analyzed to determine the exact taxonomic status of FE11. As shown in Figure 5, nodes represented the viral genomes and edges between the nodes represented the genetic similarities between them. A total of 3445 phages were selected from the vConTACT database for analysis. In Figure 5B, FE11 was marked with a red circle, indicating that it belongs to the genus Maculvirus.

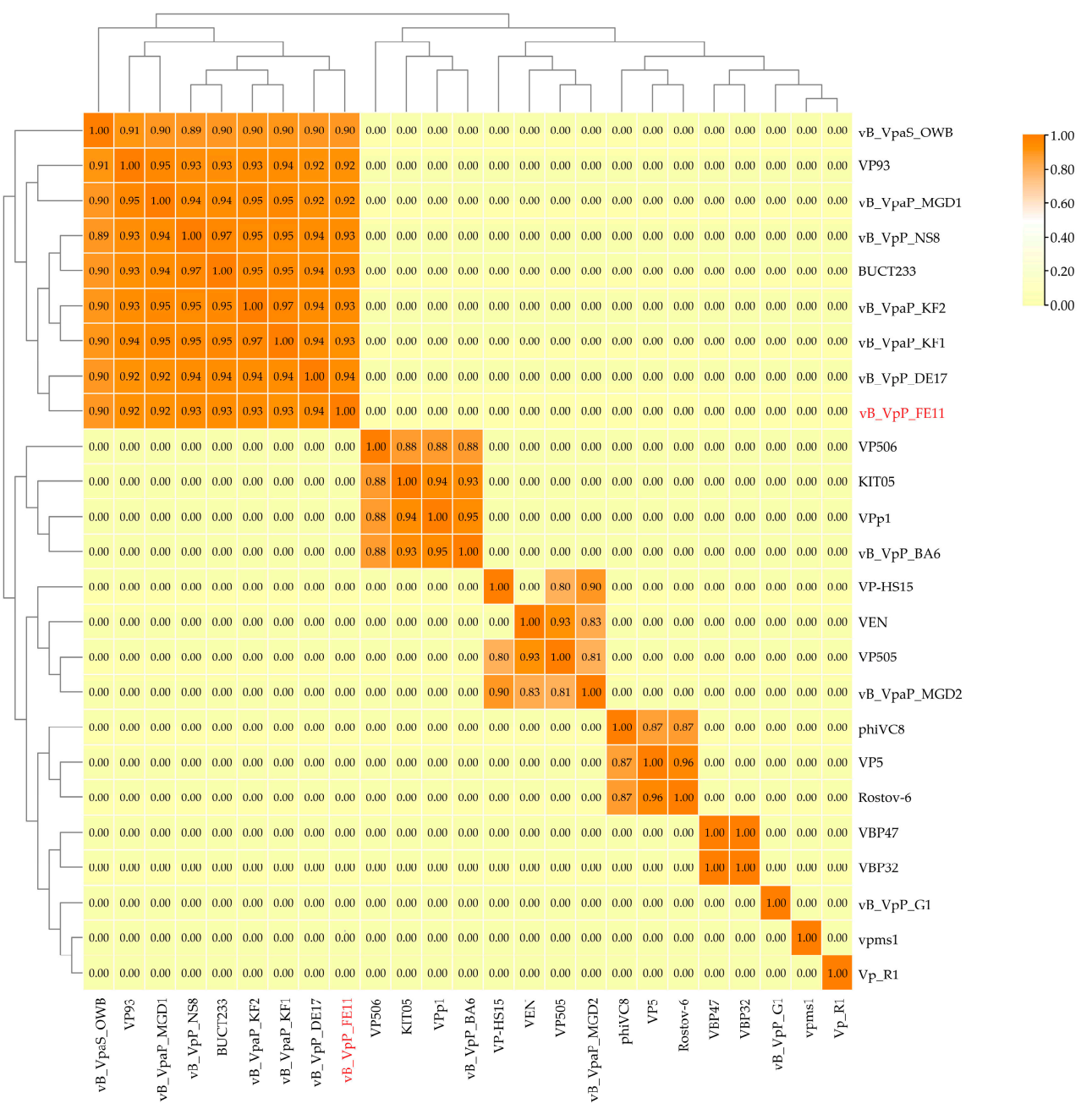

Figure 2. Average nucleotide identity heatmap. The percentage identity values range from $0(0 \%$, yellow) to $1(100 \%$, orange).

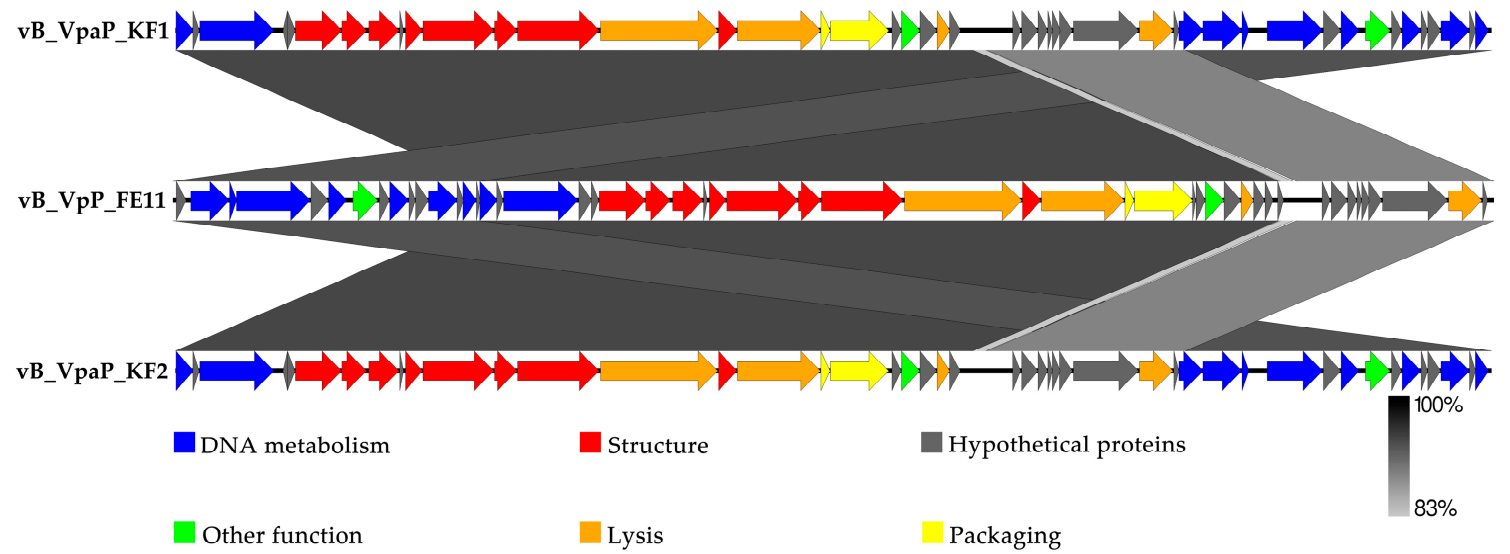

Figure 3. Comparison of the genomes of FE11, and vB_VpaP_KF1, and vB_VpaP_KF2 using Easyfig. Different colored arrows represent 50 predicted open reading frames with different functions. 


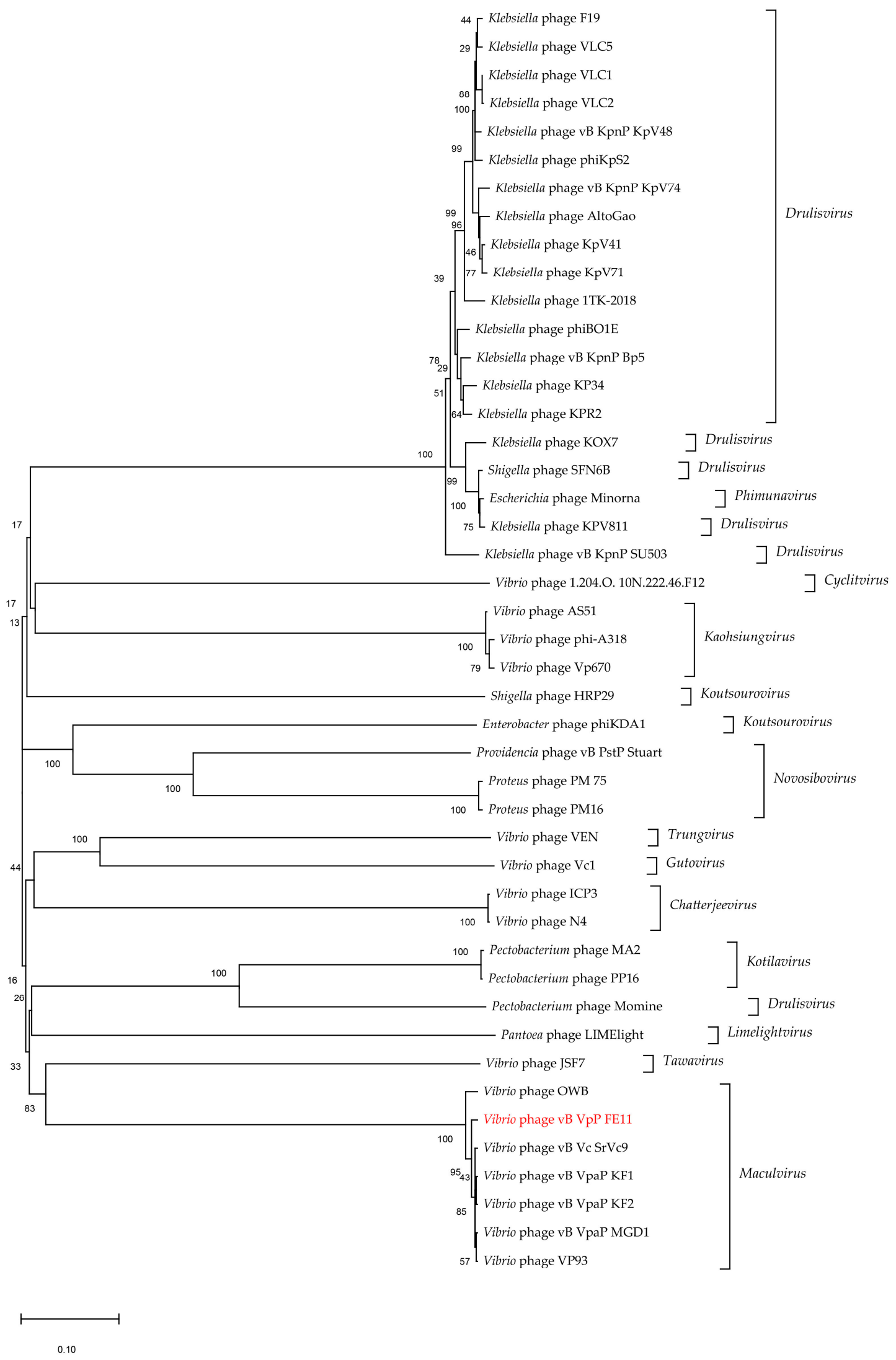

Figure 4. Phylogenetic tree of Vibrio phages in the subfamily Autographiviridae, conducted using the neighbor-joining method in MEGAX by RNA polymerases. 
A

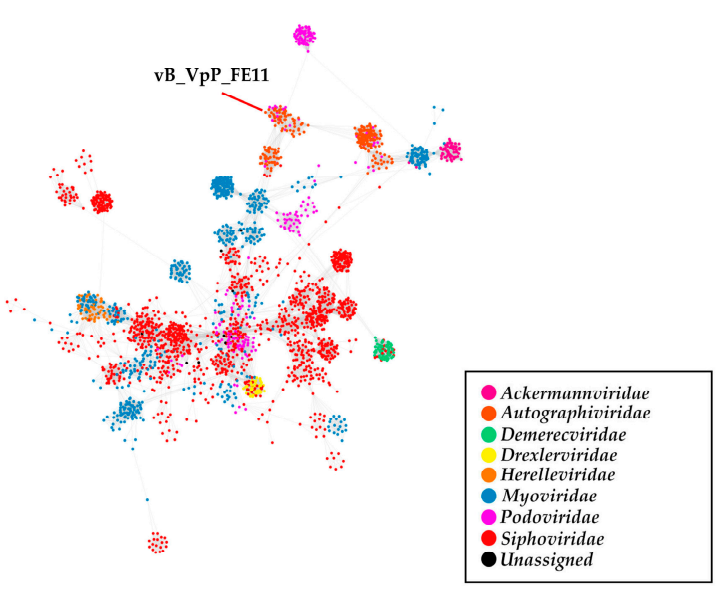

B

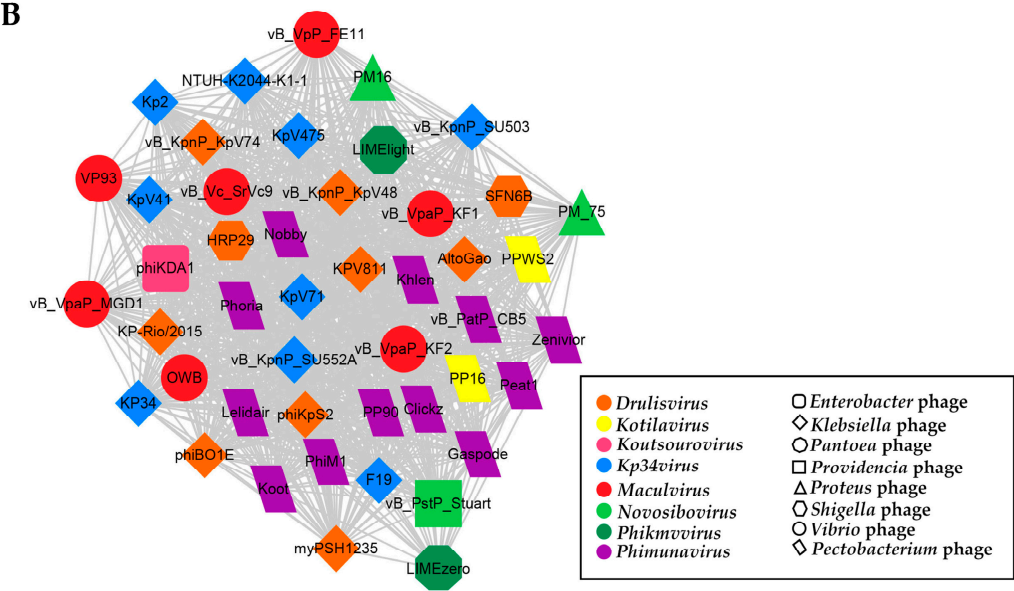

Figure 5. Protein-sharing network of FE11 benchmarked against ICTV-accepted viral taxonomy. (A) The network consists of 3445 phages (nodes) and 80,374 relationships (edges). Each node represents a viral genome, and each distinct color represents the viral family. (B) The protein cluster where FE11 was located. Different shapes represent phages with different hosts and each distinct color represents the viral genus.

\subsection{One-Step Growth Curve}

A one-step growth curve was used to elucidate the life cycle of the phage. The results showed that the latent period of FE11 (Figure 6A) was $15 \mathrm{~min}$. The lysis period was $15 \mathrm{~min}$, when the number of phages increased markedly, then plateaued. The burst size was $37 \mathrm{pfu} /$ cell.

A

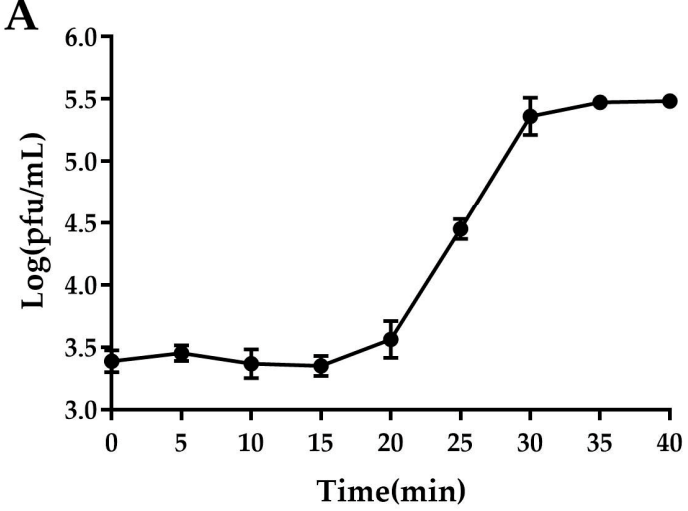

C

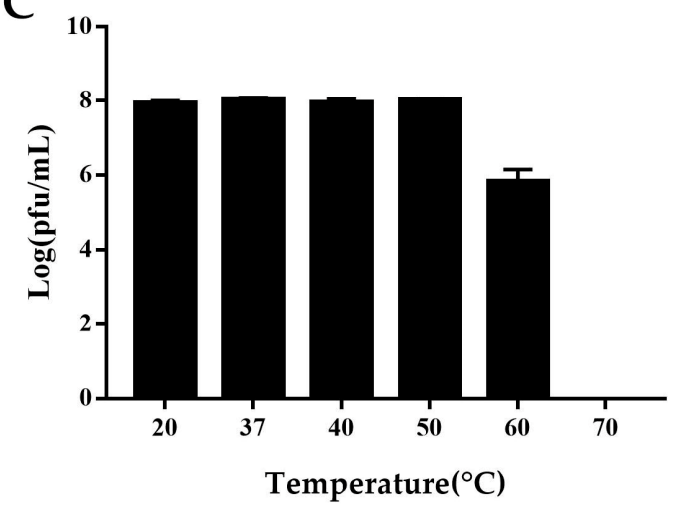

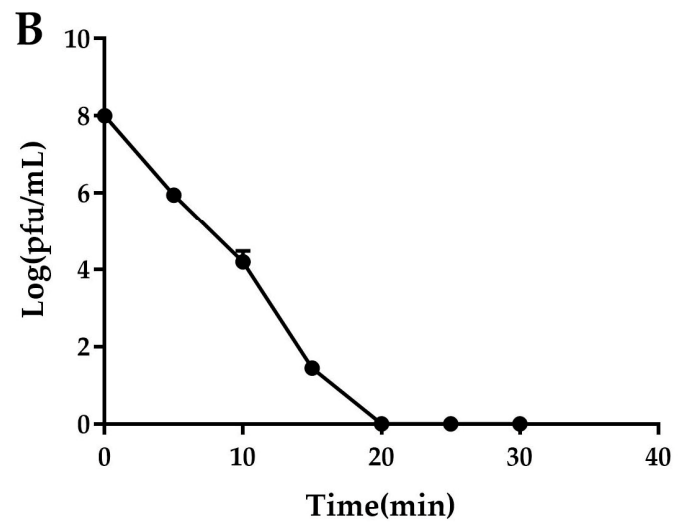

D

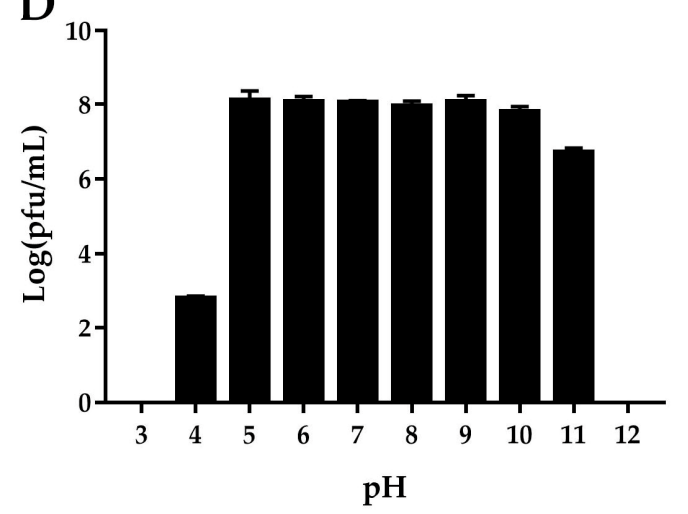

Figure 6. General characterizations of phage FE11. (A) One-step growth curve. (B) Effects of ultraviolet irradiation on phage activity. (C) Temperature tolerance. (D) $\mathrm{pH}$ tolerance. 


\subsection{Determination of Phage Stability}

Under UV light, the phage survival rate decreased sharply at approximately $2 \log$ values every $5 \mathrm{~min}$. The phage was completely inactivated after $20 \mathrm{~min}$ of UV irradiation, indicating that FE11 was sensitive to UV light (Figure 6B).

The heat stability test showed that the phage titer remained almost unchanged between 20 to $50^{\circ} \mathrm{C}$, decreased markedly at $60^{\circ} \mathrm{C}$, and the phage was completely inactivated when the temperature reached $70{ }^{\circ} \mathrm{C}$ (Figure 6C).

The phage titer remained almost constant at $\mathrm{pH}$ values ranging from 5 to 10 . Under acidic conditions, the titer decreased considerably at $\mathrm{pH}$ values from 5 to 4 , and the phage was inactivated at $\mathrm{pH} 3$. Under alkaline conditions, the phage titer decreased by approximately $1.1 \operatorname{logs}$ as the $\mathrm{pH}$ increased from 10 to 11 , and the phage was inactivated completely at $\mathrm{pH} 12$ (Figure 6D).

\subsection{Effect of Phage on Formed Biofilm}

As shown in Figure 7A, most treatments were almost ineffective for formed biofilm; however, from 2 to $5 \mathrm{~h}$, when the concentration of phages added was $1 \times 10^{10} \mathrm{pfu} / \mathrm{mL}$, the effect was significant $(p<0.01)$. This suggests that there must be a sufficient concentration of phages to destroy the formed biofilm.

A

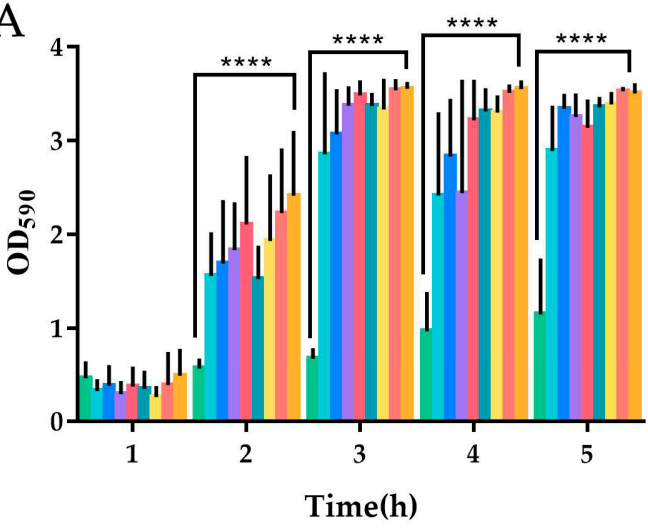

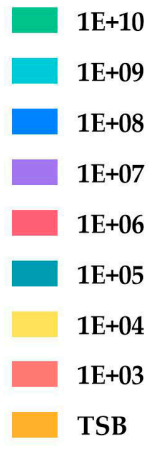

TSB
B

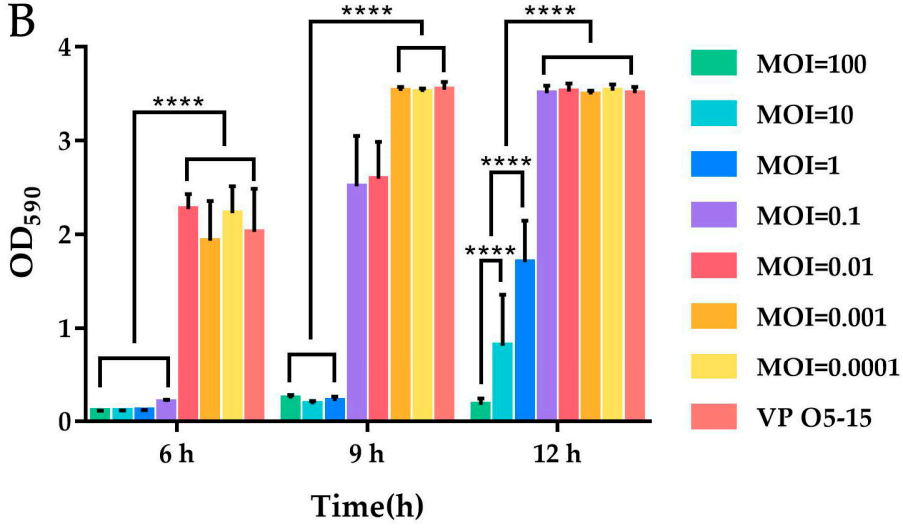

Figure 7. Effects of phage on biofilm. (A) Effects of FE11 of different titers on the preformed biofilm. Different treatments are indicated by different bar colors. ${ }^{* * *}, p<0.0001$. (B) Effects of phage co-incubation on biofilm formation. Shown are the results on the effects of FE11 at different MOIs on the biofilm formation after 6, 9, and $12 \mathrm{~h}$ of co-incubation. Control: Vibrio parahaemolyticus strain O5-15 (VP O5-15) without any phages. ${ }^{* * * *}, p<0.0001$.

\subsection{Effect of Phage on Biofilm Formation}

As shown in Figure 7B, the phage treatment could effectively control the formation of $V$. parahaemolyticus biofilm at a very low concentration at $6 \mathrm{~h}$ with MOI of 100, 10, 1, and 0.1 compared with the control and other MOIs $(p<0.01)$. With an MOI of 0.1 , there was a significant increase of OD value from $6 \mathrm{~h}$ to $9 \mathrm{~h}$, which meant the biofilm increased greatly and the effect of phage treatment decreased. When co-cultured for $12 \mathrm{~h}$, treatments with MOI of 100,10, and 1 remained effective, with MOI of 100 exhibiting the most significant effect $(p<0.01)$. The higher the MOI, the better the control and prevention effects of biofilm. The results of SEM analysis further confirmed that phages could effectively control the formation of $V$. parahaemolyticus biofilm. As shown in Figure 8A, VP O5-15 could easily form biofilms. After treatment with FE11, the amount of biofilm formed decreased markedly (Figure 8B). As shown in Figure 8C, the untreated VP O5-15 cells were complete and smooth, whereas the cells ruptured in the presence of FE11 (Figure 8D). 

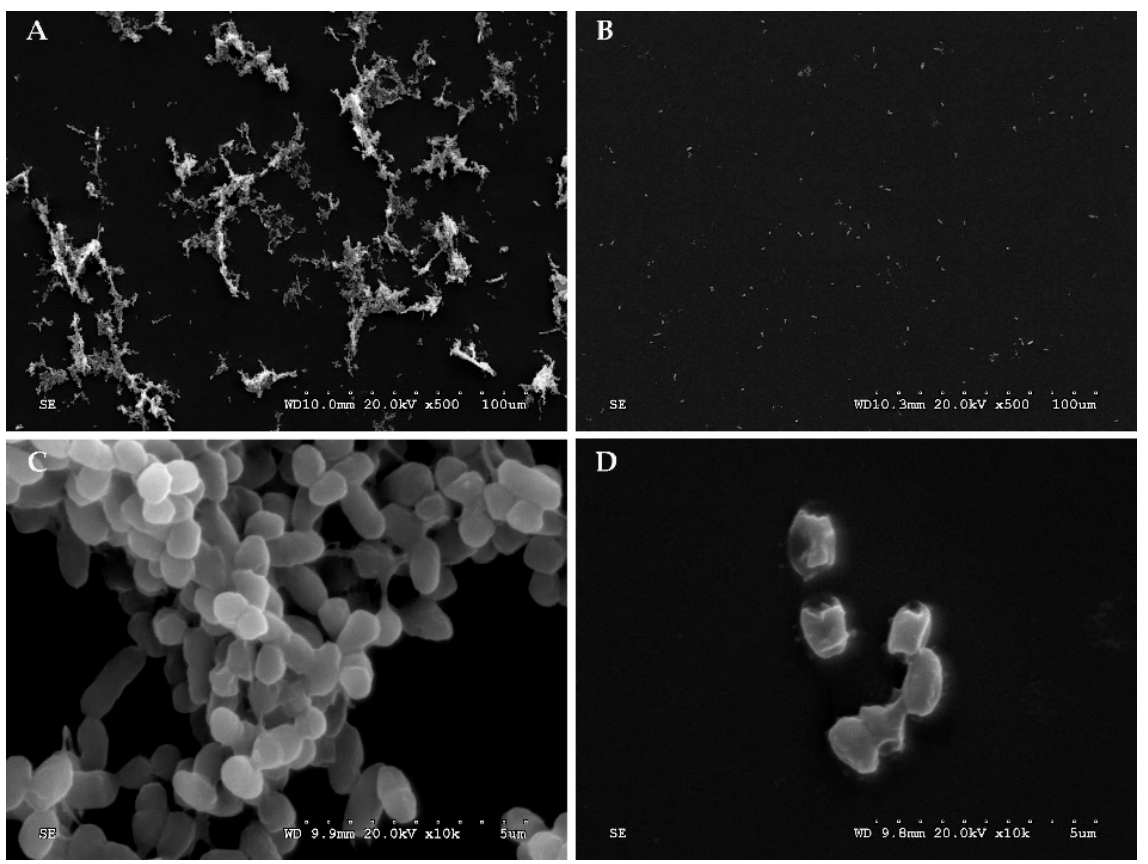

Figure 8. Scanning electron microscope imagery of $V$. parahaemolyticus O5-15 treated with phage FE11: (A,C) V. parahaemolyticus O5-15, and (B,D) V. parahaemolyticus O5-15 + FE11.

\section{Discussion}

V. parahaemolyticus infects fish, shellfish, and shrimp and is one of the main causes of seafood-borne illnesses [36,37]. V. parahaemolyticus can form biofilms in environments where food is processed [38], which is a major food safety risk in the seafood and aquaculture industries. An increasing number of antibiotic-resistant strains of $V$. parahaemolyticus have been isolated [39,40]; therefore, an effective antibacterial agent is needed to counter this. Lytic phages have the potential for use in an antibacterial strategy [41-43].

This study identified a Vibrio phage capable of infecting 26\% (35/133) of tested $V$. parahaemolyticus strains. Based on morphological observation and genome sequencing, a BLASTn search combined with ANIm analyses revealed that FE11 belongs to the family Podoviridae.

In the genome of FE11, Prokka annotation, BLASTp analysis, InterProScan, and HHpred analysis showed that the predicted gene products of FE11 are similar to those of phages KF1 and KF2, with a few differences; FE11 contains four additional predicted genes (gene 01, 34, 40 and 41) encoding hypothetical proteins. Annotation results showed that there were no genes related to lysogen formation, such as those encoding recombinases or integrases in the genome of FE11 further supporting the lytic nature of FE11.

The organization of FE11 genome showed modularity, such that genes with related function were clustered together. The upstream DNA region consisted of genes related to DNA metabolism, whereas the downstream region consisted of those related to packaging and lysis. Proteins related to DNA metabolism are involved in DNA replication and transcription. Predicted gene 18 product is RNA polymerase, allowing the classification of FE11 to Autographiviridae. FE11 was further identified as Maculvirus based on phylogenetic analysis of RNA polymerase and protein family analysis by vConTACT.

The structural module of phage genome are always associated with host recognition, especially tail-related proteins. In the structure module of FE11 genome, three tail-related proteins were predicted, including tail tubular protein A/B (TTPA/TTPB, Gp25/26) and tail fiber protein (Gp30). The TTPA and TTPB of phage OWB have been demonstrated to serve as ligands that recognize the conserved Vibrio receptor Vp0980 to mediate phage adsorption [44]. The tail fibre of phage OWB binds LPS and mediates phage infection. So phage OWB requires both tail fiber and tail tubular proteins for host recongnition. The 
amino acid sequence of FE11 TTPA, TTPB and tail fiber have high similarity to that of phage OWB (93.01\%, 94.62\% and 96.06\% identity, respectively). So we refer that the tail fiber and tail tubular proteins of phage FE11 mediate phage adsorption to host as well. But further studies are required to prove the function.

In phages, endolysin can lyse the peptidoglycan of the bacterial cell wall, thereby assisting in the release of new phages. Owing to its broad-spectrum lytic nature and the low possibility of bacterial resistance developing, endolysin has been used widely as part of antibacterial therapy [45-47]. As the outer membrane of Gram-negative bacteria hinders the permeation of exogenous endolysin, outer membrane permeabilizers (OMPs) are essential for combined use in in vitro treatment [48]. The peptidase (KF2_Lys) purified from $V$. parahaemolyticus phage KF2 reportedly showed a high lytic activity independent of OMP [49]. The predicted peptidase (Gp49) of FE11 is 93.19\% identical with the KF2_Lys strongly indicateing that the two have similar functions. Further investigations to elucidate the lytic mechanism of FE11 endolysin are warranted.

In this study, an Ig-like domain family protein (Gp36) was identified in the FE11 genome; these proteins may help phages attach to cell surfaces or eliminate pathogenic bacteria invading mucosa by binding to the mucosal surface [50].

In terms of biological characteristics, FE11 was stable at a relatively broad temperature range between 20 and $50{ }^{\circ} \mathrm{C}$, while phage vB_Vc_SrVc9 was only stable at $20-40{ }^{\circ} \mathrm{C}$, which both phages were located in the same evolutionary branch [51]. For the UV test, FE11 was completely inactivated by UV irradiation for $20 \mathrm{~min}$, but vB_Vc_SrVc9 was more sensitive and basically inactivated after $1 \mathrm{~min}$. FE11 was also stable at relatively broad pH range, suggesting that it has potential for use in aquaculture environments.

Biofilms are aggregates of bacterial cells, and their heterogeneity leads to nutrient limitation and a decrease in metabolic activity and growth rate, thereby reducing the sensitivity to antibiotics [52]. There are many studies on the application of phages to prevent and control kinds of bacterial biofilms. For example, phages were able to reduce the biofilm formation of Shiga toxin-producing Escherichia coli by $43.46 \%$ [53]. Moreover, phages prevented the formation of methicillin-resistant Staphylococcus pseudintermedius biofilms at low doses, and even degrade the biofilms at high doses [54]. However, there were few studies on $V$. parahaemolyticus biofilms. The phage $\phi \mathrm{VP}-1$ has been reported to control $V$. parahaemolyticus biofilms effectively [55]. Yin et al. showed that phages could prevent and control $V$. parahaemolyticus biofilms, but could not effectively destroy formed biofilms [56]. For phage relative productions, the endolysin of phage qdvp001 (Lysqdvp001-15 aa) could also reduce the biofilms of $V$. parahaemolyticus and inhibit the formation of the bacterial biofilms [57]. In our study, FE11 not only prevents the formation of $V$. parahaemolyticus biofilms, but also destroy the preformed biofilms at high phage concentrations.

In conclusion, the newly isolated Vibrio phage FE11 has the potential to become a biocontrol agent against $V$. parahaemolyticus.

Supplementary Materials: The following are available online at https: / www.mdpi.com/article/ 10.3390/v14020264/s1, Figure S1: The phage genome termini analysis of FE11, Table S1: Predicted functions of phage FE11 gene products.

Author Contributions: Q.W. and J.W. conceived the study. M.Y. and H.C. designed and conducted the experiments and wrote the paper. Q.H., Z.X. and Z.L. performed the genome and comparative genome analysis. J.Z., Y.D., M.C. and L.X. contributed to the data analysis. All authors have read and agreed to the published version of the manuscript.

Funding: The authors are grateful to National Natural Science Foundation of China (NSFC) (31730070), Local Innovative Scientific Research Team Project of Guangdong "Pearl River Talents Plan" (2017BT01S174), Key Research and Development Program of Guangdong (2018b020205002), Guangdong Major Project of Basic and Applied Basic Research (2020B0301030005), the Science and Technology Planning Project of Guangdong Province (2018A050506074) for financial supports.

Institutional Review Board Statement: Not applicable. 
Informed Consent Statement: Not applicable.

Data Availability Statement: The findings of this study are available within this paper and its supplementary information file. The complete genome sequence of phage vB_VpaP_FE11 was submitted to the GenBank database under accession number MT178448.

Acknowledgments: Thanks to the Institute of Microbiology, Guangdong Academy of Sciences for providing Vibrio parahaemolyticus.

Conflicts of Interest: The authors declare that the research was conducted in the absence of any commercial or financial relationships that could be construed as potential conflicts of interest.

\section{References}

1. Matsuda, S.; Hiyoshi, H.; Tandhavanant, S.; Kodama, T. Advances on Vibrio Parahaemolyticus Research in the Postgenomic Era. Microbiol. Immunol. 2020, 64, 167-181. [CrossRef] [PubMed]

2. Spaur, M.; Davis, B.J.K.; Kivitz, S.; DePaola, A.; Bowers, J.C.; Curriero, F.C.; Nachman, K.E. A Systematic Review of Post-Harvest Interventions for Vibrio Parahaemolyticus in Raw Oysters. Sci. Total Environ. 2020, 745, 140795. [CrossRef] [PubMed]

3. Lin, S.; Hsu, K.; Wang, H. Structural Insights into the Cytotoxic Mechanism of Vibrio Parahaemolyticus PirA(vp) and PirB(vp) Toxins. Mar. Drugs 2017, 15, 373. [CrossRef]

4. Nair, G.B.; Ramamurthy, T.; Bhattacharya, S.K.; Dutta, B.; Takeda, Y.; Sack, D.A. Global Dissemination of Vibrio Parahaemolyticus Serotype O3: K6 and its Serovariants. Clin. Microbiol. Rev. 2007, 20, 39-48. [CrossRef] [PubMed]

5. Hong, X.; Lu, L.; Xu, D. Progress in Research on Acute Hepatopancreatic Necrosis Disease (AHPND). Aquacult. Int. 2016, 24, 577-593. [CrossRef]

6. Song, X.; Ma, Y.; Fu, J.; Zhao, A.; Guo, Z.; Malakar, P.K.; Pan, Y.; Zhao, Y. Effect of Temperature on Pathogenic and Non-Pathogenic Vibrio Parahaemolyticus Biofilm Formation. Food Control 2017, 73, 485-491. [CrossRef]

7. Elexson, N.; Afsah-Hejri, L.; Rukayadi, Y.; Soopna, P.; Lee, H.Y.; Zainazor, T.C.T.; Ainy, M.N.; Nakaguchi, Y.; Mitsuaki, N.; Son, R. Effect of Detergents as Antibacterial Agents on Biofilm of Antibiotics-Resistant Vibrio Parahaemolyticus Isolates. Food Control 2014, 35, 378-385. [CrossRef]

8. Xie, T.; Wu, Q.; Xu, X.; Zhang, J.; Guo, W. Prevalence and Population Analysis of Vibrio Parahaemolyticus in Aquatic Products from South China Markets. FEMS Microbiol. Lett. 2015, 362, fnv178. [CrossRef]

9. Xie, T.; Xu, X.; Wu, Q.; Zhang, J.; Cheng, J. Prevalence, Molecular Characterization, and Antibiotic Susceptibility of Vibrio Parahaemolyticus from Ready-to-Eat Foods in China. Front. Microbiol. 2016, 7, 549. [CrossRef]

10. Hendrix, R.W. Bacteriophages: Evolution of the Majority. Theor. Popul. Biol. 2002, 61, 471-480. [CrossRef]

11. Zhang, J.; Cao, Z.; Li, Z.; Wang, L.; Li, H.; Wu, F.; Jin, L.; Li, X.; Li, S.; Xu, Y. Effect of Bacteriophages on Vibrio Alginolyticus Infection in the Sea Cucumber, Apostichopus Japonicus (Selenka). J. World Aquacult. Soc. 2015, 46, 149-158. [CrossRef]

12. Li, Z.; Ren, H.; Li, Q.; Murtaza, B.; Li, X.; Zhang, J.; Xu, Y. Exploring the Effects of Phage Cocktails in Preventing Vibrio Infections in Juvenile Sea Cucumber (Apostichopus Japonicus) Farming. Aquaculture 2020, 515, 734599. [CrossRef]

13. Higuera, G.; Bastias, R.; Tsertsvadze, G.; Romero, J.; Espejo, R.T. Recently Discovered Vibrio Anguillarum Phages can Protect Against Experimentally Induced Vibriosis in Atlantic Salmon, Salmo Salar. Aquaculture 2013, 392, 128-133. [CrossRef]

14. Kim, S.G.; Jun, J.W.; Giri, S.S.; Yun, S.; Kim, H.J.; Kim, S.W.; Kang, J.W.; Han, S.J.; Jeong, D.; Park, S.C. Isolation and Characterisation of pVa-21, a Giant Bacteriophage with Anti-Biofilm Potential Against Vibrio Alginolyticus. Sci. Rep. 2019, 9, 6284. [CrossRef]

15. Sasikala, D.; Srinivasan, P. Characterization of Potential Lytic Bacteriophage Against Vibrio Alginolyticus and its Therapeutic Implications on Biofilm Dispersal. Microb. Pathog. 2016, 101, 24-35. [CrossRef]

16. Van Twest, R.; Kropinski, A.M. Bacteriophage Enrichment from Water and Soil. Methods Mol. Biol. 2009, 501, 15-21. [CrossRef]

17. Ajuebor, J.; Buttimer, C.; Arroyo-Moreno, S.; Chanishvili, N.; Gabriel, E.M.; O'Mahony, J.; McAuliffe, O.; Neve, H.; Franz, C.; Coffey, A. Comparison of Staphylococcus Phage K with Close Phage Relatives Commonly Employed in Phage Therapeutics. Antibiotics 2018, 7, 37. [CrossRef]

18. Boulanger, P. Purification of Bacteriophages and SDS-PAGE Analysis of Phage Structural Proteins from Ghost Particles. Methods Mol. Biol. 2009, 502, 227-238. [CrossRef]

19. Bian, S.; Jia, Y.; Zhan, Q.; Wong, N.; Hu, Q.; Zhang, W.; Zhang, Y.; Li, L. VPsero: Rapid Serotyping of Vibrio Parahaemolyticus Using Serogroup-Specific Genes Based on Whole-Genome Sequencing Data. Front. Microbiol. 2021, 12, 2446. [CrossRef]

20. Lu, S.; Le, S.; Tan, Y.; Zhu, J.; Li, M.; Rao, X.; Zou, L.; Li, S.; Wang, J.; Jin, X.; et al. Genomic and Proteomic Analyses of the Terminally Redundant Genome of the Pseudomonas aeruginosa Phage PaP1: Establishment of Genus PaP1-Like Phages. PLoS ONE 2013, 8, e62933. [CrossRef]

21. Ahmadi, M.; Karimi Torshizi, M.A.; Rahimi, S.; Dennehy, J.J. Prophylactic Bacteriophage Administration More Effective than Post-infection Administration in Reducing Salmonella Enterica Serovar Enteritidis Shedding in Quail. Front. Microbiol. 2016, 7, 1253. [CrossRef] [PubMed]

22. Garneau, J.R.; Depardieu, F.; Fortier, L.; Bikard, D.; Monot, M. PhageTerm: A Tool for Fast and Accurate Determination of Phage Termini and Packaging Mechanism Using Next-Generation Sequencing Data. Sci. Rep. 2017, 7, 8292. [CrossRef] [PubMed] 
23. Pritchard, L.; Glover, R.H.; Humphris, S.; Elphinstone, J.G.; Toth, I.K. Genomics and Taxonomy in Diagnostics for Food Security: Soft-Rotting Enterobacterial Plant Pathogens. Anal. Methods 2016, 8, 12-24. [CrossRef]

24. Altschul, S.F.; Madden, T.L.; Schaffer, A.A.; Zhang, J.H.; Zhang, Z.; Miller, W.; Lipman, D.J. Gapped BLAST and PSI-BLAST: A New Generation of Protein Database Search Programs. Nucleic Acids Res. 1997, 25, 3389-3402. [CrossRef]

25. Mitchell, A.; Chang, H.; Daugherty, L.; Fraser, M.; Hunter, S.; Lopez, R.; McAnulla, C.; McMenamin, C.; Nuka, G.; Pesseat, S.; et al. The InterPro Protein Families Database: The Classification Resource After 15 Years. Nucleic Acids Res. 2015, 43, D213-D221. [CrossRef]

26. Söding, J.; Biegert, A.; Lupas, A.N. The HHpred Interactive Server for Protein Homology Detection and Structure Prediction. Nucleic Acids Res. 2005, 33, W244-W248. [CrossRef]

27. Kumar, S.; Stecher, G.; Li, M.; Knyaz, C.; Tamura, K. MEGA X: Molecular Evolutionary Genetics Analysis Across Computing Platforms. Mol. Biol. Evol. 2018, 35, 1547-1549. [CrossRef]

28. Bolduc, B.; Jang, H.B.; Doulcier, G.; You, Z.; Roux, S.; Sullivan, M.B. VConTACT: An iVirus Tool to Classify Double-Stranded DNA Viruses that Infect Archaea and Bacteria. PeerJ 2017, 5, e3243. [CrossRef]

29. Kropinski, A.M. Practical Advice on the One-Step Growth Curve. Methods Mol. Biol. 2018, 1681, 41-47. [CrossRef]

30. Yang, M.; Liang, Y.; Huang, S.; Zhang, J.; Wang, J.; Chen, H.; Ye, Y.; Gao, X.; Wu, Q.; Tan, Z. Isolation and Characterization of the Novel Phages vB_VpS_BA3 and vB_VpS_CA8 for Lysing Vibrio parahaemolyticus. Front. Microbiol. 2020, 11, 259. [CrossRef]

31. Imam, M.; Alrashid, B.; Patel, F.; Dowah, A.S.A.; Brown, N.; Millard, A.; Clokie, M.R.J.; Galyov, E.E. VB_PaeM_MIJ3, a Novel Jumbo Phage Infecting Pseudomonas aeruginosa, Possesses Unusual Genomic Features. Front. Microbiol. 2019, 10, 2772. [CrossRef] [PubMed]

32. Endersen, L.; Buttimer, C.; Nevin, E.; Coffey, A.; Neve, H.; Oliveira, H.; Lavigne, R.; O'Mahony, J. Investigating the Biocontrol and Anti-Biofilm Potential of a Three Phage Cocktail Against Cronobacter Sakazakii in Different Brands of Infant Formula. Int. J. Food Microbiol. 2017, 253, 1-11. [CrossRef] [PubMed]

33. Knezevic, P.; Petrovic, O. A Colorimetric Microtiter Plate Method for Assessment of Phage Effect on Pseudomonas Aeruginosa Biofilm. J. Microbiol. Meth. 2008, 74, 114-118. [CrossRef] [PubMed]

34. Yuan, Y.; Qu, K.; Tan, D.; Li, X.; Wan, L.; Cong, C.; Xiu, Z.; Xu, Y. Isolation and Characterization of a Bacteriophage and its Potential to Disrupt Multi-Drug Resistant Pseudomonas Aeruginosa Biofilms. Microb. Pathog. 2019, 128, 329-336. [CrossRef]

35. Adriaenssens, E.M.; Brister, J.R. How to Name and Classify Your Phage: An Informal Guide. Viruses 2017, 9, 70. [CrossRef]

36. Lomeli-Ortega, C.O.; Martinez-Diaz, S.F. Phage Therapy Against Vibrio Parahaemolyticus Infection in the Whiteleg Shrimp (Litopenaeus Vannamei) Larvae. Aquaculture 2014, 434, 208-211. [CrossRef]

37. Stalin, N.; Srinivasan, P. Characterization of Vibrio Parahaemolyticus and its Specific Phage from Shrimp Pond in Palk Strait, South East Coast of India. Biologicals 2016, 44, 526-533. [CrossRef]

38. Han, N.; Mizan, M.F.R.; Jahid, I.K.; Ha, S. Biofilm Formation by Vibrio Parahaemolyticus on Food and Food Contact Surfaces Increases with Rise in Temperature. Food Control 2016, 70, 161-166. [CrossRef]

39. Lopatek, M.; Wieczorek, K.; Osek, J. Antimicrobial Resistance, Virulence Factors, and Genetic Profiles of Vibrio Parahaemolyticus from Seafood. Appl. Environ. Microb. 2018, 84, e00537-18. [CrossRef]

40. Lee, L.; Ab Mutalib, N.; Law, J.W.; Wong, S.H.; Letchumanan, V. Discovery on Antibiotic Resistance Patterns of Vibrio Parahaemolyticus in Selangor Reveals Carbapenemase Producing Vibrio Parahaemolyticus in Marine and Freshwater Fish. Front. Microbiol. 2018, 9, 2513. [CrossRef]

41. Popova, K.B.; Valsamatzi-Panagiotou, A.; Penchovsky, R. New Drug Discovery Strategies for Targeting Drug-Resistant Bacteria. Environ. Chem. Lett. 2021, 19, 1995-2004. [CrossRef]

42. Pereira, C.; Costa, P.; Duarte, J.; Balcao, V.M.; Almeida, A. Phage Therapy as a Potential Approach in the Biocontrol of Pathogenic Bacteria Associated with Shellfish Consumption. Int. J. Food Microbiol. 2021, 338, 108995. [CrossRef]

43. Tian, F.; Li, J.; Nazir, A.; Tong, Y. Bacteriophage-A Promising Alternative Measure for Bacterial Biofilm Control. Infect. Drug Resist. 2021, 14, 205-217. [CrossRef] [PubMed]

44. Hu, M.; Zhang, H.; Gu, D.; Ma, Y.; Zhou, X. Identification of a Novel Bacterial Receptor that Binds Tail Tubular Proteins and Mediates Phage Infection of Vibrio Parahaemolyticus. Emerg. Microbes Infect. 2020, 9, 855-867. [CrossRef] [PubMed]

45. Kim, S.; Jin, J.; Choi, Y.; Kim, J. LysSAP26, a New Recombinant Phage Endolysin with a Broad Spectrum Antibacterial Activity. Viruses 2020, 12, 1340. [CrossRef]

46. Son, B.; Kong, M.; Cha, Y.; Bai, J.; Ryu, S. Simultaneous Control of Staphylococcus Aureus and Bacillus Cereus Using a Hybrid Endolysin LysB4EAD-LysSA11. Antibiotics 2020, 9, 906. [CrossRef]

47. Abdelrahman, F.; Easwaran, M.; Daramola, O.I.; Ragab, S.; Lynch, S.; Oduselu, T.J.; Khan, F.M.; Ayobami, A.; Adnan, F.; Torrents, E.; et al. Phage-Encoded Endolysins. Antibiotics 2021, 10, 124. [CrossRef] [PubMed]

48. Lai, W.C.B.; Chen, X.; Ho, M.K.Y.; Xia, J.; Leung, S.S.Y. Bacteriophage-Derived Endolysins to Target Gram-Negative Bacteria. Int. J. Pharmaceut. 2020, 589, 119833. [CrossRef] [PubMed]

49. Lim, J.; Lee, N.; Chun, H.; Chang, H. Characterization of a Novel Endolysin From Bacteriophage infecting Vibrio Parahaemolyticus, vB_VpaP_KF2. Appl. Biol. Chem. 2020, 63, 40. [CrossRef]

50. Barr, J.J.; Auro, R.; Furlan, M.; Whiteson, K.L.; Erb, M.L.; Pogliano, J.; Stotland, A.; Wolkowicz, R.; Cutting, A.S.; Doran, K.S.; et al. Bacteriophage Adhering to Mucus Provide a Non-Host-Derived Immunity. Proc. Natl. Acad. Sci. USA 2013, 110, 10771-10776. [CrossRef] 
51. Lomelí-Ortega, C.O.; Martínez-Sández, A.J.; Barajas-Sandoval, D.R.; Reyes, A.G.; Magallón-Barajas, F.; Veyrand-Quíros, B.; Gannon, L.; Harrison, C.; Michniewski, S.; Millard, A.; et al. Isolation and Characterization of Vibrio phage vB_Vc_SrVc9: An Effective Agent in Preventing Vibrio Campbellii Infections in Brine Shrimp Nauplii (Artemia Franciscana). J. Appl. Microbiol. 2021, 131, 36-49. [CrossRef] [PubMed]

52. Latka, A.; Drulis-Kawa, Z. Advantages and Limitations of Microtiter Biofilm Assays in the Model of Antibiofilm Activity of Klebsiella Phage KP34 and its Depolymerase. Sci. Rep. 2020, 10, 20338. [CrossRef] [PubMed]

53. Mangieri, N.; Foschino, R.; Picozzi, C. Application of Bacteriophages on Shiga Toxin-Producing Escherichia Coli (STEC) Biofilm. Antibiotics 2021, 10, 1423. [CrossRef] [PubMed]

54. Kim, S.G.; Giri, S.S.; Yun, S.; Kim, S.W.; Han, S.J.; Kwon, J.; Oh, W.T.; Lee, S.B.; Park, Y.H.; Park, S.C. Two Novel Bacteriophages Control Multidrug- and Methicillin-Resistant Staphylococcus Pseudintermedius Biofilm. Front. Med. 2021, 8, 359. [CrossRef]

55. Matamp, N.; Bhat, S.G. Genome Characterization of Novel Lytic Myoviridae Bacteriophage $\phi V P-1$ Enhances its Applicability Against MDR-biofilm-forming Vibrio Parahaemolyticus. Arch. Virol. 2020, 165, 387-396. [CrossRef]

56. Yin, Y.; Ni, P.; Liu, D.; Yang, S.; Almeida, A.; Guo, Q.; Zhang, Z.; Deng, L.; Wang, D. Bacteriophage Potential Against Vibrio Parahaemolyticus Biofilms. Food Control 2019, 98, 156-163. [CrossRef]

57. Ning, H.; Cong, Y.; Lin, H.; Wang, J. Development of Cationic Peptide Chimeric Lysins Based on Phage Lysin Lysqdvp001 and their Antibacterial Effects Against Vibrio Parahaemolyticus: A Preliminary Study. Int. J. Food Microbiol. 2021, 358, 109396. [CrossRef] 